\title{
Genetic parameters for type score traits and milk production in Brazilian Jersey herds
}

\author{
Mayara Andressa Sabedot', Gabrieli de Souza Romano', Victor Breno Pedrosa ${ }^{2}$, \\ Luís Fernando Batista Pinto ${ }^{1^{*}}$ iD
}

\footnotetext{
${ }^{1}$ Universidade Federal da Bahia, Escola de Medicina Veterinária e Zootecnia, Departamento de Zootecnia, Salvador, BA, Brasil.

${ }^{2}$ Universidade Estadual de Ponta Grossa, Departamento de Zootecnia, Ponta Grossa, PR, Brasil.
}

\begin{abstract}
This study aimed to estimate the heritability coefficients for ten functional type traits and milk production in the Jersey breed in Brazil, besides the genetic and phenotypic correlations between them. The present study utilised data from 1,567 records of linear type traits, including stature (ST), body depth (BD), loin strength (LS), rump width (RW), rump angle (RA), fore udder attachment (FUA), front teat placement (FTP), rear udder height (RUH), central ligament (CL), and final score (FS). Milk yield (MY) adjusted to 305 lactation days was also calculated. Covariance components were estimated by the restricted maximum likelihood approach using the PEST and VCE6 programs on the animal model. Heritability coefficients thus assessed were as follows: $0.22 \pm 0.01$ (ST), $0.35 \pm 0.07$ (BD), $0.17 \pm 0.01$ (RW), $0.55 \pm 0.05$ (RA), $0.09 \pm 0.01$ (LS), $0.20 \pm 0.02$ (FUA), $0.40 \pm 0.06$ (FTP), $0.40 \pm 0.06$ (RUH), $0.15 \pm 0.02$ (CL), $0.21 \pm 0.02$ (FS), and $0.16 \pm 0.02$ (MY). Therefore, the higher genetic gain will be obtained for BD, RA, FTP, and RUH, while the other traits would need a medium or long-term period to show improvement. The genetic correlations fell in the range from $0.01(\mathrm{FTP} \times \mathrm{FS})$ to $0.87(\mathrm{RW} \times \mathrm{CL})$, and the only genetic correlation noted between FS and RA was negative $(-0.10 \pm 0.06)$. Thus, in the Jersey breed in Brazil, the type traits are genetically associated, and the selection of any one of them may elicit an indirect response in another.
\end{abstract}

Key Words: dairy cattle, genetic correlation, heritability, selection

\section{Introduction}

The linear type traits form an interesting set of traits for dairy farmers as they are related to appearance, breed pattern as well as productive performance of cows, throughout their lifetimes (Kern et al., 2015). Thus, traits associated with rump, feet and legs, dairy strength, and mammary system have been monitored since the time the Jersey breeding programs commenced across the world (Norman et al., 1978).

Heritability estimates for the functional type traits were reported for the Jersey breed in the United States (Norman and Van Vleck, 1972; Norman et al., 1978; Norman et al., 1988; Gengler et al., 1997; Wiggans et al., 2004); Italy (Biscarini et al., 2003) and South Africa (Van Niekerk et al., 2000; Theron and Mostert, 2004; Du Toit et al., 2012). Although some estimates of heritability reported in these

Received: May 9, 2017

Accepted: May 18, 2018

*Corresponding author: luisfbp@gmail.com

Copyright (C) 2018 Sociedade Brasileira de Zootecnia. This is an Open Access article distributed under the terms of the Creative Commons Attribution License (http://creativecommons.org/licenses/by/4.0/), which permits unrestricted use, distribution, and reproduction in any medium, provided the original work is properly cited. studies were moderate, in a few instances, they were high, reiterating that most type traits possess the potential to be used as selection criteria. Furthermore, Visscher and Goddard (1995) and Zink et al. (2014) demonstrated that a positive correlation existed between some type traits and milk yield, which can cause an indirect milk yield escalation, when some conformation traits are used as selection criteria.

However, until now, no reports of the estimation of genetic parameters are available for the type score traits in Brazilian Jersey herds, which reveal difficulties in establishing selection criteria for these cows in the country. As the Brazilian milk system is predominantly pasture-oriented, unlike most other countries where feedlots predominate, genetic parameters estimated in these latter countries may not be suitable references for the Brazilian herds. Hence, this study aimed at determining the heritability coefficient for the type traits and milk yield in Jersey cows from the Brazilian herds, as well as genetic and phenotypic correlations between these traits.

\section{Material and Methods}

The analyses, using data from 1,567 records of ten type traits and milk yield of first lactation cows, collected 
between 2000 and 2011, from 16 herds in six of the Brazilian states (CE, GO, MG, PR, SC and SP), were performed by the Brazilian Jersey Breeders Association (BJBA). The relationship matrix included the information drawn from a total of 2,786 animals, including sires and dams. The traits studied (Table 1) were stature (ST), body depth (BD), loin strength (LS), rump width (RW), rump angle (RA), fore udder attachment (FUA), front teat placement (FTP), rear udder height (RUH), central ligament (CL), final score (FS), and milk yield (MY).

Dairy cattle were assessed using the International method of evaluation to measure the type traits according to the World Holstein Friesian Federation (WHFF, 2005). The BJBA estimated the trait scores per WHFF recommendations; thus, all the scores fell within the range from 1 (one) to 9 (nine); an authorised official of the Holstein Association was the classifier who determined these scores and who was, therefore, well-versed in the WHFF-established regulations. The BJBA included loin strength and final score in the assessment, with loin strength ranging from 1 (low strength) to 9 (immense strength), while the final score was the sum of scores from all the 21 type traits evaluated. Data from cows below 20 months of age or more than 48 months of age were excluded.

Data on type traits were tested for normality (ShapiroWilk) before being evaluated. All traits showed normal distribution $(\mathrm{P}>0.05)$. The animal model included random effects of the additive genetic value and residual value for each animal in each trait. Besides, the earlier analysis of variance (not shown) performed in the SAS program (Statistical Analysis System, version 9.3) revealed significant effects $(\mathrm{P}<0.05)$ for all the fixed effects included in both models employed.

The analyses included two models, the first being selected for type traits and the second for milk yield. The effects investigated in the first model included fixed effects of the contemporary group (herd, year of classification, and period of classification: 1 = December to February; $2=$ March to May; $3=$ June to August; and $4=$ September to November), with age at the time of calving used as a covariate (linear and quadratic), beyond the random additive genetic and residual effects. The classifier effect was excluded from this model because the same individual had evaluated all the cows. The second model was similar to the first, but the contemporary group (herd, year, and season of calving) also took into account the four seasons being considered (December to February; March to May; June to August; and September to November). Contemporary groups that revealed less than three records were excluded from both models.

Using the multi-trait method, the variance components were estimated. Five traits were analysed, until the relationships among all the traits had been investigated. The model used is represented by $y=X b+Z a+e$, in which $y$ is the vector of the dependent variables, $X$ is the incidence matrix for the fixed effects, $b$ is the vector of the solutions for the fixed effects, $Z$ is the incidence matrix for the additive genetic effects, $a$ is the vector of the solutions for the random additive effects, and $e$ is the vector of the random residual effects.

The components of the models for analysis are represented simply as given:

Table 1 - Descriptive values of the type traits and milk yield in 1,567 Jersey cows

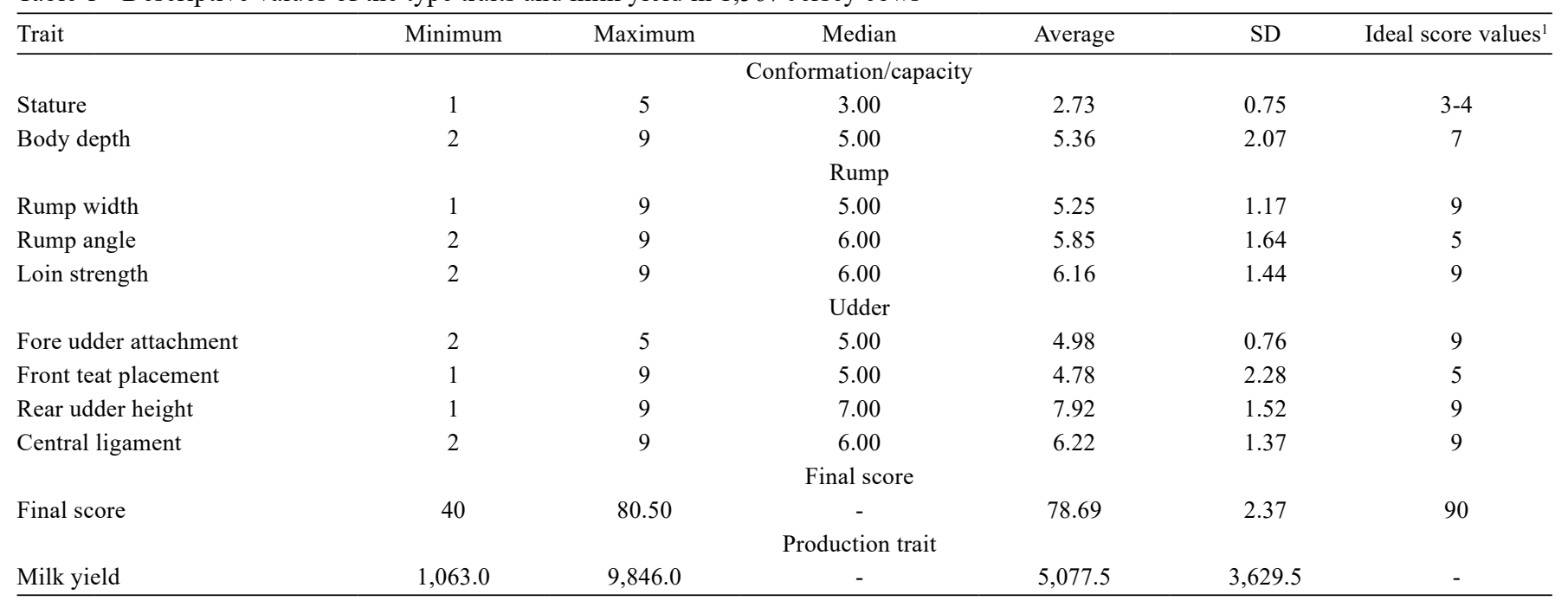

SD - standard deviation.

${ }^{1}$ Ideal values according to Brazilian Jersey Breeders Association.
. 


$$
E\left[\begin{array}{l}
y \\
a \\
e
\end{array}\right]=\left[\begin{array}{c}
X b \\
0 \\
0
\end{array}\right] \text { and } V\left[\begin{array}{l}
a \\
e
\end{array}\right]=\left[\begin{array}{cc}
G & 0 \\
0 & R
\end{array}\right]
$$

The multi-trait model is represented as:

$$
\mathrm{E}\left[\begin{array}{c}
\mathrm{Y}_{1} \\
\mathrm{Y}_{2} \\
\mathrm{Y}_{3} \\
\mathrm{Y}_{4} \\
\mathrm{Y}_{5}
\end{array}\right]=\left[\begin{array}{ccccc}
\mathrm{X}_{1} & 0 & 0 & 0 & 0 \\
0 & \mathrm{X}_{2} & 0 & 0 & 0 \\
0 & 0 & \mathrm{X}_{3} & 0 & 0 \\
0 & 0 & 0 & \mathrm{X}_{4} & 0 \\
0 & 0 & 0 & 0 & \mathrm{X}_{5}
\end{array}\right]\left[\begin{array}{c}
\beta_{1} \\
\beta_{2} \\
\beta_{3} \\
\beta_{4} \\
\beta_{5}
\end{array}\right],
$$

in which the subscripts $1,2,3,4$, and 5 represent the traits evaluated and considered in each analysis. The (co)variance matrix for the genetic effects is $\mathrm{G}=\mathrm{G} \otimes \mathrm{A}$, in which $\mathrm{A}$ is the genetic relationship matrix and $\mathrm{G}_{0}$ is the matrix (of order 5), as follows:

$$
\mathrm{G}=\left[\begin{array}{ccccc}
\sigma_{g 1}^{2} & \sigma_{g 1,2} & \sigma_{g 1,3} & \sigma_{g 1,4} & \sigma_{g 1,5} \\
\sigma_{g 1,2} & \sigma_{g 2}^{2} & \sigma_{g 2,3} & \sigma_{g 2,4} & \sigma_{g 2,5} \\
\sigma_{g 1,3} & \sigma_{g 2,3} & \sigma_{g 3}^{2} & \sigma_{g 3,4} & \sigma_{g 3,5} \\
\sigma_{g 1,4} & \sigma_{g 2,4} & \sigma_{g 3,4} & \sigma_{g 4}^{2} & \sigma_{g 4,5} \\
\sigma_{g 1,5} & \sigma_{g 2,5} & \sigma_{g 3,5} & \sigma_{g 4,5} & \sigma_{g 5}^{2}
\end{array}\right],
$$

in which $\mathrm{G}=\mathrm{A} \otimes \mathrm{G}$ is an additive genetic variance matrix between the traits and $\mathrm{R}=\mathrm{I} \otimes \mathrm{R}_{0}$ is the residual (co) variance matrix (of order 5) between each of the five traits under consideration in each analysis. The animal model was used to determine the variance components and genetic parameters employing the restricted maximum likelihood (REML) approach, using the VCE6 (Groeneveld et al., 2010) and PEST (Groeneveld, 2006) programs.

\section{Results}

Stature $(0.22 \pm 0.01)$ and BD $(0.35 \pm 0.07)$ revealed moderate heritability coefficients (Table 2), while the genetic correlations of ST with the other traits were in the range of 0.15 to 0.74 (Table 3); for $\mathrm{BD}$, however, the genetic correlations ranged from 0.20 to 0.84 .

In the present study, three traits associated with rump conformation were assessed. For LS $(0.09 \pm 0.01)$ and RW $(0.17 \pm 0.01)$, low heritability estimates were determined, but for RA $(0.55 \pm 0.05)$, a high heritability was estimated. For these traits, the genetic correlations (Table 3 ) fell within the range of $-0.10(\mathrm{RA} \times \mathrm{FS})$ to $0.87(\mathrm{RW} \times \mathrm{CL})$.

The udder conformation traits FUA, FTP, RUH, and CL were assessed in the present study. Fore udder attachment $(0.20 \pm 0.02)$, FTP $(0.40 \pm 0.06)$, and RUH $(0.40 \pm 0.06)$ displayed the more expressive heritability values, while CL showed low heritability $(0.15 \pm 0.02)$. For these traits, the genetic correlations (Table 3 ) ranged from $0.01(\mathrm{FTP} \times \mathrm{FS})$ to $0.87(\mathrm{CL} \times \mathrm{RW})$.

The final score demonstrated a moderate coefficient of heritability $(0.21 \pm 0.02)$, while the genetic correlations (Table 3) involving this trait ranged between 0.01 (FS $\times$ FTP ) and $0.43(\mathrm{FS} \times \mathrm{CL})$. Finally, MY $(0.16 \pm 0.02)$ revealed a low estimate of heritability, and the genetic correlations (Table 3 ) between this trait and the type scores ranged from $0.15(\mathrm{MY} \times \mathrm{ST})$ to $0.74(\mathrm{MY} \times \mathrm{BD})$.

\section{Discussion}

The average values for ST and BD in the Jersey herds in Brazil were found to fall below the ideal values for ST (between 3 and 4) and BD (7), which indicated the need to increase these scores. The coefficients of heritability for ST $(0.22 \pm 0.01)$ and BD $(0.35 \pm 0.07)$ were found to be moderate, with the response to selection falling in the midterm period. The heritability for ST was within the 0.20 to 0.43 range, concurring with the results from other studies on the Jersey breed (Table 4), while the estimate for BD crossed the highest value $(0.27)$ recorded in the earlier studies (Table 4). However, the increase in the ST and BD estimations may have implications for other traits, due to the high genetic correlations (Table 3 ). Genetic correlations involving ST and DB observed in the present study corresponded to the results of studies performed earlier on Jersey cows, because Norman et al. (1978), Gengler et al. (1997), Wiggans et al. (2004), and Biscarini et al. (2003) also reported mainly positive genetic correlations between these traits (ST and $\mathrm{BD}$ ) and other type-score traits in the Jersey breed. Besides, our results confirmed those of Vallimont et al. (2010), namely, that deeper bodies are genetically related to more productive cows, due to the positive high genetic correlation between MY and BD $(0.74 \pm 0.09)$.

According to BJBA, the ideal LS, RW, and RA scores are 9,9 , and 5 , respectively. Thus, the average scores for LS (6.16) and RW (5.25) fell below the ideal values, while the average value for RA (5.85) indicate that it would be beneficial to reduce this score in the Brazilian Jersey cows. Low estimates of heritability were observed for LS $(0.09 \pm 0.01)$ and RW $(0.17 \pm 0.01)$, but a high heritability value was noted for RA $(0.55 \pm 0.05)$. Therefore, genetic gains are anticipated for RA over the short term, while similar gains will require a long-term period for the improvement of LS and RW via direct selection. Earlier studies on the Jersey breed (Table 4) reported heritability in 
Table 2 - Estimates of additive genetic $\left(\sigma_{\mathrm{a}}^{2}\right)$, residual $\left(\sigma_{\mathrm{e}}^{2}\right)$, and phenotypic $\left(\sigma_{\mathrm{p}}^{2}\right)$ variance components and heritability (h⿻) to the type traits in the Brazilian Jersey cows

\begin{tabular}{|c|c|c|c|c|}
\hline Trait & $\sigma_{a}^{2}$ & $\sigma_{e}^{2}$ & $\sigma_{p}^{2}$ & $\mathrm{~h}^{2}$ \\
\hline \multicolumn{5}{|c|}{ Conformation/capacity } \\
\hline Stature & 0.1569 & 0.5636 & 0.7205 & $0.22 \pm 0.01$ \\
\hline Body depth & 0.5298 & 0.9731 & 1.5029 & $0.35 \pm 0.07$ \\
\hline Rump width & 0.2244 & 1.1029 & 1.3273 & $0.17 \pm 0.01$ \\
\hline Rump angle & 0.9636 & 0.7836 & 1.7473 & $0.55 \pm 0.05$ \\
\hline Loin strength & 0.2140 & 2.0679 & 2.2819 & $0.09 \pm 0.01$ \\
\hline Fore udder attachment & 0.7159 & 2.8539 & 3.5698 & $0.20 \pm 0.02$ \\
\hline Front teat position & 0.7860 & 1.1639 & 1.9502 & $0.40 \pm 0.06$ \\
\hline Rear udder height & 0.5134 & 0.7581 & 1.2734 & $0.40 \pm 0.06$ \\
\hline Central ligament & 0.2802 & 1.5941 & 1.8743 & $0.15 \pm 0.02$ \\
\hline \multicolumn{5}{|c|}{ Final score } \\
\hline Final score & 1.4100 & 5.4500 & 6.8600 & $0.21 \pm 0.02$ \\
\hline
\end{tabular}

Table 3 - Estimates of genetic (above the diagonal) and phenotypic (below diagonal) correlations between the type traits and their standard errors

\begin{tabular}{lccccccccccc}
\hline & ST & BD & LS & RW & RA & FUA & FTP & RUH & CL & FS & MY \\
\hline ST & & $0.66(0.14)$ & $0.74(0.16)$ & $0.32(0.08)$ & $0.68(0.12)$ & $0.38(0.09)$ & $0.52(0.11)$ & $0.54(0.09)$ & $0.65(0.12)$ & $0.19(0.08)$ & $0.15(0.04)$ \\
BD & $0.51(0.02)$ & & $0.35(0.09)$ & $0.52(0.11)$ & $0.84(0.14)$ & $0.66(0.14)$ & $0.56(0.09)$ & $0.45(0.06)$ & $0.42(0.11)$ & $0.20(0.06)$ & $0.74(0.09)$ \\
LS & $0.44(0.02)$ & $0.31(0.01)$ & & $0.21(0.07)$ & $0.55(0.08)$ & $0.72(0.13)$ & $0.54(0.08)$ & $0.26(0.08)$ & $0.45(0.10)$ & $0.21(0.05)$ & $0.65(0.11)$ \\
RW & $0.35(0.01)$ & $0.45(0.02)$ & $0.21(0.02)$ & & $0.10(0.05)$ & $0.65(0.10)$ & $0.32(0.06)$ & $0.74(0.11)$ & $0.87(0.11)$ & $0.23(0.05)$ & $0.54(0.09)$ \\
RA & $-0.65(0.03)$ & $0.45(0.01)$ & $0.88(0.04)$ & $0.21(0.02)$ & & $0.55(0.08)$ & $0.55(0.10)$ & $0.26(0.08)$ & $0.50(0.08)$ & $-0.10(0.06)$ & $0.32(0.07)$ \\
FUA & $0.55(0.03)$ & $0.33(0.01)$ & $0.76(0.03)$ & $0.25(0.01)$ & $0.66(0.03)$ & & $0.40(0.11)$ & $0.65(0.12)$ & $0.47(0.08)$ & $0.41(0.08)$ & $0.45(0.10)$ \\
FTP & $0.45(0.02)$ & $0.35(0.02)$ & $0.78(0.04)$ & $0.35(0.01)$ & $0.42(0.02)$ & $0.81(0.05)$ & & $0.40(0.07)$ & $0.77(0.12)$ & $0.01(0.04)$ & $0.15(0.06)$ \\
RUH & $0.56(0.03)$ & $0.58(0.02)$ & $0.61(0.03)$ & $0.32(0.02)$ & $0.62(0.03)$ & $0.71(0.03)$ & $0.23(0.02)$ & & $0.45(0.11)$ & $0.42(0.09)$ & $0.23(0.07)$ \\
CL & $0.69(0.04)$ & $0.54(0.02)$ & $0.68(0.03)$ & $0.87(0.03)$ & $0.35(0.02)$ & $0.69(0.04)$ & $0.35(0.02)$ & $0.74(0.04)$ & & $0.43(0.10)$ & $0.36(0.08)$ \\
FS & $0.31(0.01)$ & $0.24(0.01)$ & $0.23(0.02)$ & $0.30(0.02)$ & $-0.08(0.01)$ & $0.48(0.03)$ & $-0.06(0.01)$ & $0.46(0.03)$ & $0.47(0.02)$ & & $0.48(0.09)$ \\
MY & $0.10(0.01)$ & $0.15(0.02)$ & $0.05(0.01)$ & $0.20(0.02)$ & $0.35(0.02)$ & $0.40(0.03)$ & $0.15(0.02)$ & $0.54(0.03)$ & $0.56(0.02)$ & $0.24(0.02)$ & \\
\hline
\end{tabular}

ST - stature; BD - body depth; LS - loin strength; RW - rump width; RA - rump angle; FUA - fore udder attachment; FTP - front teat placement; RUH - rear udder height; CL central ligament; FS - final score; MY - milk yield.

Table 4 - Estimates of heritability coefficients for type traits in other reported studies on the Jersey breed

\begin{tabular}{|c|c|c|c|c|c|c|c|c|c|c|c|}
\hline Reference & Country & ST & $\mathrm{BD}$ & LS & RW & RA & FUA & FTP & RUH & $\mathrm{CL}$ & FS \\
\hline Norman and Van Vleck (1972) & USA & - & 0.20 & - & - & 0.12 & 0.02 & - & 0.16 & - & - \\
\hline Norman et al. (1978) & USA & 0.43 & - & - & - & - & 0.22 & - & - & 0.11 & 0.23 \\
\hline Norman et al. (1988) & USA & 0.27 & - & 0.19 & - & 0.27 & 0.19 & - & 0.18 & 0.23 & 0.11 \\
\hline Visscher and Goddard (1995) & USA & 0.42 & - & - & - & - & 0.21 & 0.31 & - & 0.36 & - \\
\hline Gengler et al. (1997) & USA & 0.40 & 0.27 & 0.26 & 0.22 & 0.41 & 0.22 & 0.29 & 0.28 & - & 0.29 \\
\hline Van Niekerk et al. (2000) & South Africa & 0.32 & - & 0.23 & 0.17 & 0.22 & 0.17 & - & 0.26 & - & - \\
\hline Theron and Mostert (2004) & South Africa & 0.20 & 0.18 & - & 0.09 & 0.16 & 0.07 & 0.17 & 0.15 & 0.09 & - \\
\hline Wiggans et al. (2004) & USA & 0.37 & - & 0.21 & 0.18 & 0.22 & 0.19 & 0.20 & 0.26 & - & 0.19 \\
\hline Biscarini et al. (2003) & Italy & 0.37 & 0.25 & - & 0.17 & 0.29 & - & - & 0.17 & - & 0.23 \\
\hline Du Toit et al. (2012) & South Africa & 0.20 & 0.14 & 0.10 & 0.07 & 0.17 & 0.09 & 0.23 & 0.13 & - & - \\
\hline
\end{tabular}

ST - stature; BD - body depth; LS - loin strength; RW - rump width; RA - rump angle; FUA - fore udder attachment; FTP - front teat placement; RUH - rear udder height; CL central ligament; FS - final score.

the low to moderate range for these traits, with values from 0.10 to 0.26 (LS), 0.09 to 0.22 (RW), and 0.12 to 0.41 (RA). Therefore, the literature appears to present a consensus in suggesting that while LS and RW show low to moderate heritability, RA can record a high value for this parameter. Loin strength, RW, and RA (Table 3) revealed positive genetic correlations in general, the only exception being the value $-0.10(\mathrm{RA} \times \mathrm{FS})$. Therefore, other type traits can be employed to raise the values of LS and RW. For instance, RUH showed a genetic correlation of $0.74 \pm 0.11$ with RW, while FTP revealed $0.54 \pm 0.08$ with CL, and both RUH and FTP recorded high heritability (Table 2). Gengler et al. 
(1997) and Wiggans et al. (2004) reported positive genetic correlations for RW as well. Gengler et al. (1997) recorded a genetic correlation of -0.17 between RA and FUA, whereas the remaining positive correlations were closer to zero. Wiggans et al. (2004) and Biscarini et al. (2003) reported values below 0.30 for the genetic correlations between RA and other traits.

According to the BJBA, the ideal FUA, RUH, CL, and FTP scores are 9, 9, 9, and 5, respectively. Thus, the average values for FUA (4.98), RUH (7.92), and CL (6.22) were observed to fall below the ideal values, while FTP had an average of 4.78 , close to the ideal value. Front teat placement $(0.40 \pm 0.06)$ and RUH $(0.40 \pm 0.06)$ demonstrated greater expressive values of heritability, while FUA $(0.20 \pm 0.02)$ and $\mathrm{CL}(0.15 \pm 0.02)$ had lower values among the traits in this group. The genetic correlations (Table 3) involving FUA, RUH, CL, and FTP ranged from $0.01(\mathrm{FTP} \times \mathrm{FS})$ to $0.87(\mathrm{CL} \times \mathrm{RW})$, which implied that other type traits can be used to improve FUA and CL via indirect selection. For example, FUA showed a genetic correlation of $0.65 \pm 0.12$ with RUH, while CL showed $0.77 \pm 0.12$ of genetic correlation with FTP, and both RUH and FTP exhibited high heritability (Table 2).

In Brazil, the final score is an index resulting from the sum of the scores of 21 linear type traits. In the present study, an average final score of 78.69 was registered (Table 1), although according to the BJBA recommendations, the ideal final score is 90 points. The heritability estimated in this study $(0.21 \pm 0.02)$ suggests that the selection to improve the final score would produce genetic gains in the midterm period. Due to the large number of type traits, many farmers select the final score as the selection criterion, with the expectation of enhancing all the type traits. In several instances, the genetic correlations involving the final score and other type traits reveal low to moderate values (Table 3 ). It is significant that different score weights are assigned to individual traits comprising the final score and, therefore, that some type traits are anticipated to exhibit less genetic strength in the final score. Despite this, other studies also reported a low genetic correlation between the final score and a few specific type traits in the Jersey cattle (Gengler et al., 1997; Biscarini et al., 2003), which may partially explain the higher phenotypic (co)variance observed in the Jersey breed as against that expressed by the Holstein cattle, for instance.

The low heritability $(0.16 \pm 0.02)$ exhibited for milk yield does not concur with the result from other studies investigating the Jersey breed (Gacula Jr. et al., 1968; Deb et al., 1974; Ahlborn and Dempfle, 1992; Campos et al., 1994; Visscher and Goddard, 1995; Musani and Mayer, 1997; Roman and Wilcox, 2000; Guo et al., 2002; Dionello et al., 2006; Missanjo et al., 2013; Zambrano et al., 2014). The values reported in these studies hovered between 0.21 and 0.46. However, Sharma et al. (1983) reported a heritability factor of 0.14 for milk yield in the Jersey breed, when they used the milk yield of 305 days alone (i.e. based on a 305-day milk yielding period), and 0.26 when they employed a random regression model involving ten evaluations during the first lactation. This could be the reason for the decrease in the value noted in this study, as the 305-day milk yield period was also used here.

Milk yield revealed a higher genetic correlation with $\mathrm{BD}, \mathrm{LS}, \mathrm{RW}$, and FUA traits, although all the other type traits demonstrated positive genetic correlations with MY, although lower in value. This indicates that the selection employed to increase type traits can induce an increase in milk yield. Van Niekerk et al. (2000) reported all positive genetic correlations between MY and ST (0.33), RA (0.10), RW (0.37), FUA (0.20), and RUH (0.70). However, generally, the magnitude was less than that of the present study. The results of this study support earlier results of Dube et al. (2009) for a high genetic correlation between FUA and MY, as a superior FUA would be more desirable, as well as cows that produce for a greater number of lactations.

The results of the present study imply that the type traits BD, RW, FTP, RUH, and FS could be recommended for application in the selection programs dealing with the Jersey cattle in Brazil. These traits, besides possessing moderate to high coefficients of heritability, also presented beneficial genetic correlations with the other significant type traits and milk production.

\section{Conclusions}

The Jersey breed in Brazil revealed genetic variability in the milk yield and type traits; however, depending on the trait, the genetic gain can be obtained over a short- or mid-term period.

The type traits in the Jersey breed in Brazil are genetically related, and the selection of any of them may induce an indirect response in another trait.

All the type traits revealed positive genetic correlation with milk yield, and their selection to increase milk yield may raise the score values of type traits.

\section{Acknowledgments}

The authors thank the Brazilian Jersey Breeders Association (BJBA), for the dataset, and the Coordenação de Aperfeiçoamento de Pessoal de Nível Superior (CAPES), for the scholarship granted to Mayara Andressa Sabedot. 


\section{References}

Ahlborn, G. and Dempfle, L. 1992. Genetic parameters for milk production and body size in New Zealand Holstein-Friesian and Jersey. Livestock Production Science 31:205-219. https://doi. org/10.1016/0301-6226(92)90018-Y

Biscarini, F.; Biffani, S. and Canavesi, F. 2003. Genetic analysis of type traits for the Italian Jersey breed. Interbull Bulletin 31:80-83.

Campos, M. S.; Wilcox, C. J.; Becerril, C. M. and Diz, A. 1994. Genetic parameters for yield and reproductive traits of Holstein and Jersey cattle in Florida. Journal of Dairy Science 77:867-873. https://doi.org/10.3168/jds.S0022-0302(94)77021-1

Deb, R. N.; Gobble, J. L.; Hargrove, G. L. and Thoele, H. W. 1974. Lactation records of Jersey cattle in Pennsylvania: season of calving, phenotypic trend, heritability, and genetic trend. Journal of Dairy Science 57:884-888. https://doi.org/10.3168/jds.S0022-0302(74)84981-7

Dionello, N. J. L.; Silva, C. A. S.; Costa, C. N. and Cobuci, J. A. 2006. Estimação de parâmetros genéticos utilizando-se a produção de leite no dia do controle em primeiras lactações de vacas da raça Jersey. Revista Brasileira de Zootecnia 35:1646-1652. https://doi.org/10.1590/S1516-35982006000600010

Du Toit, J.; Van Wyk, J. B. and Maiwashe, A. 2012. Relationship between functional herd life and conformation traits in the South African Jersey Breed. South African Journal of Animal Science 42:47-54.

Dube, B.; Dzama, K.; Banga, C. B. and Norris, D. 2009. An analysis of the genetic relationship between udder health and udder conformation traits in South African Jersey cows. Animal 3:494-500. https://doi.org/10.1017/S175173110800390X

Gacula Jr., M. C.; Gaunt, S. N. and Damon Jr, R. A. 1968. Genetic and environmental parameters of milk constituents for five breeds. II. Some genetic parameters. Journal of Dairy Science 51:438-444. https://doi.org/10.3168/jds.S0022-0302(68)87003-1

Gengler, N.; Wiggans, G. R.; Wright, J. R.; Norman, H. D. and Wolfe, C. W. 1997. Estimation of (co)variance components for Jersey type traits using a repeatability model. Journal of Dairy Science 80:1801-1806. https://doi.org/10.3168/jds.S0022-0302(97)76114-9

Groeneveld, E. 2006. PEST user's manual. Institute of Animal Science press, Neustadt. Available at: <ftp://ftp.tzv.fal.de/pub/ pest/doc/pest-manual-Apr-2006.pdf $>$. Accessed on: Jan. 28, 2016.

Groeneveld, E.; Kovac, M. and Mielenz, N. 2010. VCE User's Guide and reference manual version 6.0. Institute of Farm Animal Genetics press, Neustadt. Available at: <ftp://ftp.tzv.fal.de/pub/ vce6/doc/vce6-manual-3.1-A4.pdf $>$. Accessed on: Jan. 28, 2016.

Guo, Z.; Lund, M. S. and Madsen, P. 2002. Genetic parameter estimation for milk yield over multiple parties and various lengths of lactation in Danish Jerseys by random regression models. Journal of Dairy Science 85:1596-1606. https://doi.org/10.3168/ jds.S0022-0302(02)74230-6

Kern, E. L.; Cobuci, J. A.; Costa, C. N.; McManus, C. M. and Braccini Neto, J. 2015. Genetic association between longevity and linear type traits of Holstein cows. Scientia Agricola 72:203-209. https://doi.org/10.1590/0103-9016-2014-0007

Missanjo, E.; Imbayarwo-Chikosi, V. and Halimani, T. 2013. Estimation of genetic and phenotypic parameters for production traits and somatic cell count for Jersey dairy cattle in Zimbabwe. ISRN Veterinary Science 2013:470585. https://doi.org/ $10.1155 / 2013 / 470585$
Musani, S. K. and Mayer, M. 1997. Genetic and environmental trends in a large commercial Jersey herd in the central rift valley, Kenya. Tropical Animal Health and Production 29:108-116. https://doi.org/10.1007/BF02632330

Norman, H. D.; Cassell, B. G.; Dickinson, F. N. and Wright, E. E. 1978. Phenotypic and genetic relationships between type classification traits in Jerseys. Journal of Dairy Science 61:12501256. https://doi.org/10.3168/jds.S0022-0302(78)83714-X

Norman, H. D.; Powell, R. L.; Wright, J. R. and Cassell, B. G. 1988. Phenotypic and genetic relationship between linear functional type traits and milk yield for five breeds. Journal of Dairy Science 71:1880-1896. https://doi.org/10.3168/jds.S0022-0302(88)79758-1

Norman, H. D. and Van Vleck, L. D. 1972. Type Appraisal: II. Variation in type traits due to sires, herds, and years. Journal of Dairy Science 55:1717-1725. https://doi.org/10.3168/jds.S00220302(72)85749-7

Roman, R. M. and Wilcox, C. J. 2000. Bivariate animal model estimates of genetics, phenotypic and environmental correlation for production and somatic cells in Jerseys. Journal of Dairy Science 83:829-8325. https://doi.org/10.3168/jds.S0022-0302(00)74946-0

Sharma, A. K.; Rodriguez, L. A.; Mekonnen, G.; Wilcox, C. J.; Bachman, K. C. and Collier, R. J. 1983. Climatological and genetic effects on milk composition and yield. Journal of Dairy Science 66:119-126. https://doi.org/10.3168/jds.S0022-0302(83)81762-7

Theron, H. E. and Mostert, B. E. 2004. Genetic analyses for conformation traits in South African Jersey and Holstein cattle. South African Journal of Animal Science 34:47-49. https://doi. org/10.4314/sajas.v34i6.3828

Van Niekerk, D. J.; Neser, F. W. C. and Erasmus, G. J. 2000. Genetic parameter estimates for type traits in the South African Jersey breed. South African Journal of Animal Science 30:186-192. https://doi.org/10.4314/sajas.v30i3.3851

Vallimont, J. E.; Dechow, C. D.; Daubert, J. M.; Dekleva, M. W.; Blum, J. W.; Barlieb, C. M.; Liu, W.; Varga, G. A.; Heinrichs, A. J. and Baumrucker, C. R. 2010. Genetic parameters of feed intake, production, body weight, body condition score, and selected type traits of Holstein cows in commercial tie-stall barns. Journal of Dairy Science 93:4892-4901. https://doi.org/10.3168/jds.2010-3189

Visscher, P. M. and Goddard, M. E. 1995. Genetic parameters for milk yield, survival, workability, and type traits for Australian dairy cattle. Journal of Dairy Science 78:205-220. https://doi. org/10.3168/jds.S0022-0302(95)76630-9

WHFF - World Holstein Friesian Federation. 2005. International type evaluation of dairy cattle. Available at: $<\mathrm{http} / / \mathrm{www}$.holstein-dhv. de/services/files/international\%20type\%20evaluation_WHFF. pdf $>$. Accessed on: Nov. 10, 2015

Wiggans, G. R.; Gengler, N. and Wright, J. R. 2004. Type trait (co) variance components for five dairy breeds. Journal of Dairy Science 87:2324-2330. https://doi.org/10.3168/jds.S0022-0302(04)70054-5

Zambrano, J. C.; Rincón, J. C. and Echeverri, J. J. 2014. Parámetros genéticos para caracteres productivos y reproductivos en Holstein y Jersey Colombiano. Archivos de Zootecnia 63:495-506. https://doi.org/10.4321/S0004-05922014000300010

Zink, V.; Zavadilová, L.; Lassen, J.; Štípková, M.; Vacek, M. and Štolc, L. 2014. Analyses of genetic relationships between linear type traits, fat-to-protein ratio, milk production traits, and somatic cell count in first-parity Czech Holstein cows. Czech Journal of Animal Science 59:539-547. https://doi.org/10.17221/7793-CJAS 